\title{
Re-evaluation of the Mesozoic complexes of Darnó Hill (NE Hungary) and comparisons with Neotethyan accretionary complexes of the Dinarides and Hellenides - preliminary data
}

\author{
Sándor Kovácst, János Haas* \\ Geological, Geophysical and Space Science Research \\ Group of the Hungarian Academy of Sciences, Budapest \\ Ladislav A. Palinkaš \\ Department of Mineralogy and Petrology \\ Faculty of Science, University of Zagreb, Zagreb

\section{Sándor Józsa} \\ Department of Petrology, Faculty of Sciences \\ Eötvös Loránd University, Budapest
}

\author{
Péter Ozsvárt \\ Research Group for Paleontology \\ Hungarian Academy of Sciences-HNMH, Budapest \\ Gabriella Kiss, Ferenc Molnár \\ Department of Mineralogy \\ Eötvös Loránd University, Budapest \\ Szilvia Kövér \\ Geological, Geophysical and Space Science Research \\ Group of the Hungarian Academy of Sciences \\ Budapest
}

The Mesozoic complex of Darnó Hill area in NE Hungary, according to well core documentation, is made up of two units. The upper unit, the Darnó Unit s.s., consists predominantly of blocks of ophiolitic rocks (pillow and massive basalt, gabbro) and subordinate abyssal sediments (red radiolarite and red pelagic mudstone of either Ladinian-Carnian or Bathonian-Callovian age, as well as bluish-grey, sometimes blackish siliceous shale of the latter age). The basalt is geochemically of MOR type, based on earlier evaluations. However, it comes in two types: reddish or greenish amygdaloidal pillow basalts with peperitic facies containing reddish micritic limestone inclusions, and green basalts without any sedimentary carbonate inclusion. The former type is probably MiddleTriassic, advanced rifting stage-related basalt, whereas the latter is probably of Jurassic age, corresponding to the Szarvaskô-type basalt of the western Bükk Mountains. Pre-Miocene presence of an ultramafic sheet above the complex is indicated by serpentinite pebbles in the Lower Miocene Darnó Conglomerate.

The lower unit, corresponding to the Mónosbél Unit of the western Bükk Mountains, consists of lower slope and toe-of-slope type sediments: dark grey shale and bluish-grey siliceous shale of Jurassic age, both showing distal turbiditic character, with frequently interbedded carbonate turbidites and debris flow deposits containing $\mathrm{cm}$ - to $\mathrm{dm}$-sized limestone and micaceous sandstone clasts. One to ten m-sized slide blocks of reddish, siliceous Triassic Bódvalenke-type limestone associated with the above-mentioned reddish, amygdaloidal basalt also occur. In one of the studied cores a block comprising evaporitic siliciclastics akin to those of the Middle Permian Szentlélek Formation and black, fossiliferous limestone similar to the Upper Permian Nagyvisnyó Limestone Formation of the Bükk Mountains, was also encountered.

\footnotetext{
Addresses: J. Haas, G. Kiss, F. Molnár, S. Józsa, Sz. Kövér: H-1117 Budapest, Pázmány P. sétány 1/c, Hungary

L. A. Palinkaš: 10000 Zagreb, Horvatovac 44, Croatia P. Ozsvárt: H-1083 Budapest, Ludovika tér 2, Hungary *Corresponding author; e-mail: haas@ludens.elte.hu

Received: January 14, 2011; accepted: April 26, 2011
} 
A preliminary comparison with similar Triassic advanced rifting-type basalt and limestone/ radiolarite of the western ophiolite zone of the Balkan Peninsula is presented (Fig. 1): the Zagorje region of NW Croatia, the Zlatibor-Zlatar Mountains of SW Serbia, and the North Pindos and Othrys Mountains, as well as Euboea Island, of Northern Greece. We propose the terms "Loggitsi Basalt" for such Triassic basalt containing peperitic facies, after the village of Loggitsion located in the central part of the Othrys Mts, and "Bódvalenke Limestone" for the transitional facies between Hallstatt Limestone and Triassic red radiolarite, after the village of Bódvalenke located in the Rudabánya Hills. The northwesternmost occurrence of both of these typical Neotethyan formations can be found in NE Hungary (Darnó Hill and Bódva Unit of Rudabánya Hills, respectively).

Key words: ophiolite, early rift-type basalt, peperitic facies, pelagic limestone, radiolarite, carbonate turbidite, Triassic, Jurassic, Neotethys, Greece, Croatia, Hungary, Serbia

\section{Introduction}

Mesozoic basaltic rocks are exposed in an area of about $7 \mathrm{~km}^{2}$ between Recsk and Sirok on Darnó Hill, in the immediate neighborhood of the Miocene andesitic volcanic complex of the Mátra Mts, NE Hungary. The complex was explored by three continuously cored boreholes in the 1970s (Rm-131, -135 and -136) to a depth of $1,200 \mathrm{~m}$. The first detailed review of the drill core sequences, with a re-evaluation of the entire complex, was prepared by Balla et al. (1980, 1981) and Zelenka et al. (1983). A fourth borehole, not involved in our study, also encountered the ophiolite complex beneath the Miocene volcanics (Varga et al. 1976).

In the 1990s new petrologic (Józsa 1999), radiolarian biostratigraphic (Dosztály 1994 and in Józsa et al. 1996) and sedimentological studies were carried out, together with a new, dip-related graphical documentation of the cored sections (Kovács and Józsa in Józsa et al. 1996 and in Dosztály et al. 2002). This was followed by re-mapping of the area by Gulácsi, Kovács and Gecse in 2004-2007. The first visits of Greek colleagues (G. Migiros, V. Tselepidis) who directed the attention of local geologists to the fact that similar formations are known in much larger surface exposures in Northern Greece (Othrys and North Pindos Mts), were greatly beneficial for the re-evaluation of the complex. Likewise significant progress resulted from joint field visits by L. Palinkaš (Zagreb), who demonstrated here the presence of peperitic basalt facies studied in detail by him in the Kalnik Mts of NW Croatia. A detailed comparison of volcanologic, mineralogical and petrologic characteristics of basaltic units of the Darnó Hill area with the similar units in the Kalnik Mts has been performed by Kiss (2007) and Kiss et al. (2008).

Herein only a brief summary of the main results is given, suitable for largescale comparison (Fig. 1). 


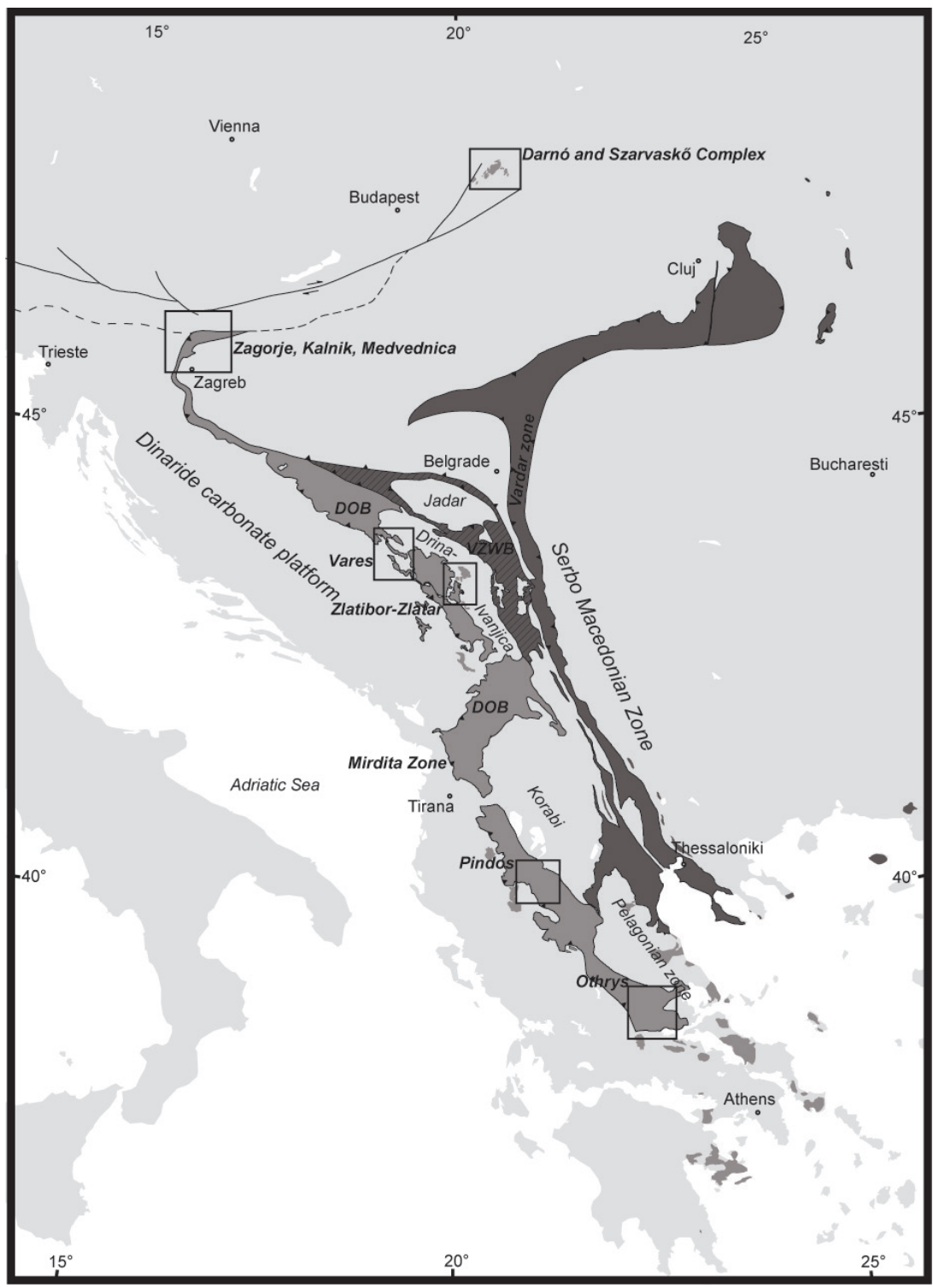

Mesozoic ophiolite and volcanic-sedimentary mélange belt in NW part of Neotethys Vardar Zone Western Belt (VZWB)

Main Vardar Zone (MVZ)

Fig. 1

Neotethyan ophiolite belts in the Carpathians, Dinarides and Hellenides, and their dismembered fragments (=small-sized "disrupted terranes" of Neotethyan oceanic origin) in the CircumPannonian region. (Base map simplified after Schmid et al. 2008). The study areas are framed 


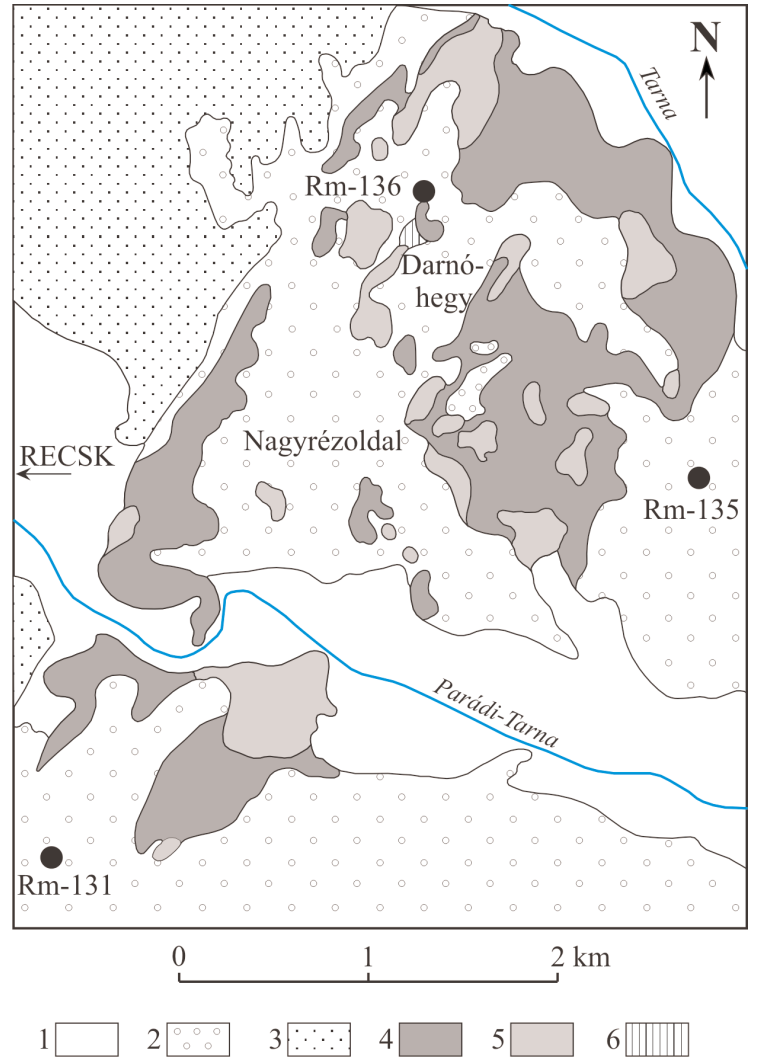

Fig. 2

Geologic map of the Darnó area showing location of the referred cored wells. 1. Quarternary; 2. Miocene; 3. Oligocene; 4 Mesozoic basalts; 5. Jurassic shale, melange; 6 . Permian shale and limestone

\section{Jurassic mélange of the Darnó Hill area}

The Mesozoic complex of the Darnó Hill area (Fig. 2), although occurring adjacent to the Miocene volcanic complex of the Mátra Mts and even in part forming its basement (as revealed by borehole Sirok-1; Varga et al. 1975), forms the westward continuation of the Bükk structures, as already demonstrated on the map by Schréter (1952).

The Darnó Hill area is located within the Darnó Fault Zone. However, as far as the pre-Tertiary basement is concerned, it does not represent a "terrane boundary", since Jurassic formations akin to those occurring in the Western Bükk were encountered in a number of boreholes in the Recsk area to the NW. Nevertheless the uppermost, ophiolitic complex is not known NW of the fault zone.

Re-evaluation of the three cores mentioned above (Rm-131, Rm-135 and Rm136; for location see Fig. 2) has revealed that the Darnó Hill area is made up of a Jurassic mélange complex. It consists of a lower unit containing olistoliths, mostly 
of sedimentary origin, and an upper one in which magmatic olistoliths are predominant (Figs 3 and 4).

The lower unit (corresponding to the Mónosbél Unit of the western Bükk Mts) represents a lower slope and toe-of-slope setting (Fig. 5c-k), where three types of gravity flow deposits alternate.

- Dark grey shale and bluish-grey siliceous shale; they show either autochthonous pelagic basin facies characteristics or laminated, very distal turbiditic features.

- Carbonate turbidites of two types: grey, marly, peloidal or micritic limestone (Oldal-völgy type of the SW Bükk Mts) - distal turbidites, and light-grey, ooliticbioclastic limestone (Bükkzsérc-type of the SW Bükk Mts; Haas et al. 2006) proximal turbidites. Dark grey to black chert layers or lenses may also occur. Sediment movements subsequent to the settling of turbidites resulted in slump structures, or formation of plasticlastic-intraclastic interbeds.

- Debris flow deposits ("micro-olistostromes") occur in certain intervals, with $\mathrm{cm}$-sized micaceous sandstone lithoclasts. Of interest is the occurrence of plutonic (granite) and extrusive (dacite-rhyolite and andesite) rock fragments in the clasts, which may have been derived from a magmatic arc (B. Árgyelán and Gulácsi 1997); however, their age is not yet determined.

Olistoliths of Triassic deep-water sediments (Bódvalenke-type, reddish-whitish siliceous limestone with red chert; Kovács 2011) associated with reddish, amygdaloidal pillow basalt also occur as slide blocks in the lower unit. The red chert yielded Ladinian-Carnian radiolarians (Dosztály and Józsa 1992; Dosztály 1994). About $900 \mathrm{~m}$ below the surface borehole Rm-136 penetrated a block of fossiliferous Upper Permian limestone (corresponding to the Nagyvisnyó Limestone) and evaporitic Middle Permian (corresponding to the Szentlélek Formation in the Bükk Mts). A surface occurrence of such an Upper Permian limestone block is known from about $250 \mathrm{~m}$ from the location of the borehole (Kiss 1958; Fülöp 1994).

The upper unit (Darnó Unit s.s.) consists predominantly of pillow and massive basalt and subordinately of deep-sea deposits, i.e. red radiolarite and mudstone, and bluish-grey, sometimes dark grey to black siliceous mudstone penetrated in a thickness of a few to tens of meters. The red radiolarite alternately yielded Triassic (Ladinian-Carnian) or Jurassic (Bathonian-Callovian) radiolarians in the different horizons, whereas only Jurassic (Callovian) ones were found in the bluish-grey silicite. Core Rm-135 also encountered intrusive rocks (gabbro, microgabbro) in several hundred meters of virtual thickness. Geochemically, these magmatic rocks were classified as MORB-type, with high Ti-content (Józsa 1999), although intra-plate basalt origin was recently proven in some Triassic blocks (Kiss et al., in press). K-Ar radiometric dating did not provide unambiguous results: although the gabbro yielded Middle Jurassic (175-165 Ma) ages, the basalt showed the age of a Middle Cretaceous tectonothermal event (110-95 Ma; Dosztály and Józsa 1992). 
Megascopically, two types of basalt can be distinguished. There is amygdaloidal basalt, usually of red or reddish but locally of greenish color. It is rich in pink and white calcite amygdals, and contains pink and reddish carbonate mudstone inclusions and inter-pillow void fillings in its peperitic facies (Fig. 5a, b). Other common facies corresponding to the lateral zoning of volcanic features in and around a submarine basaltic mound are the closely-packed pillow and the

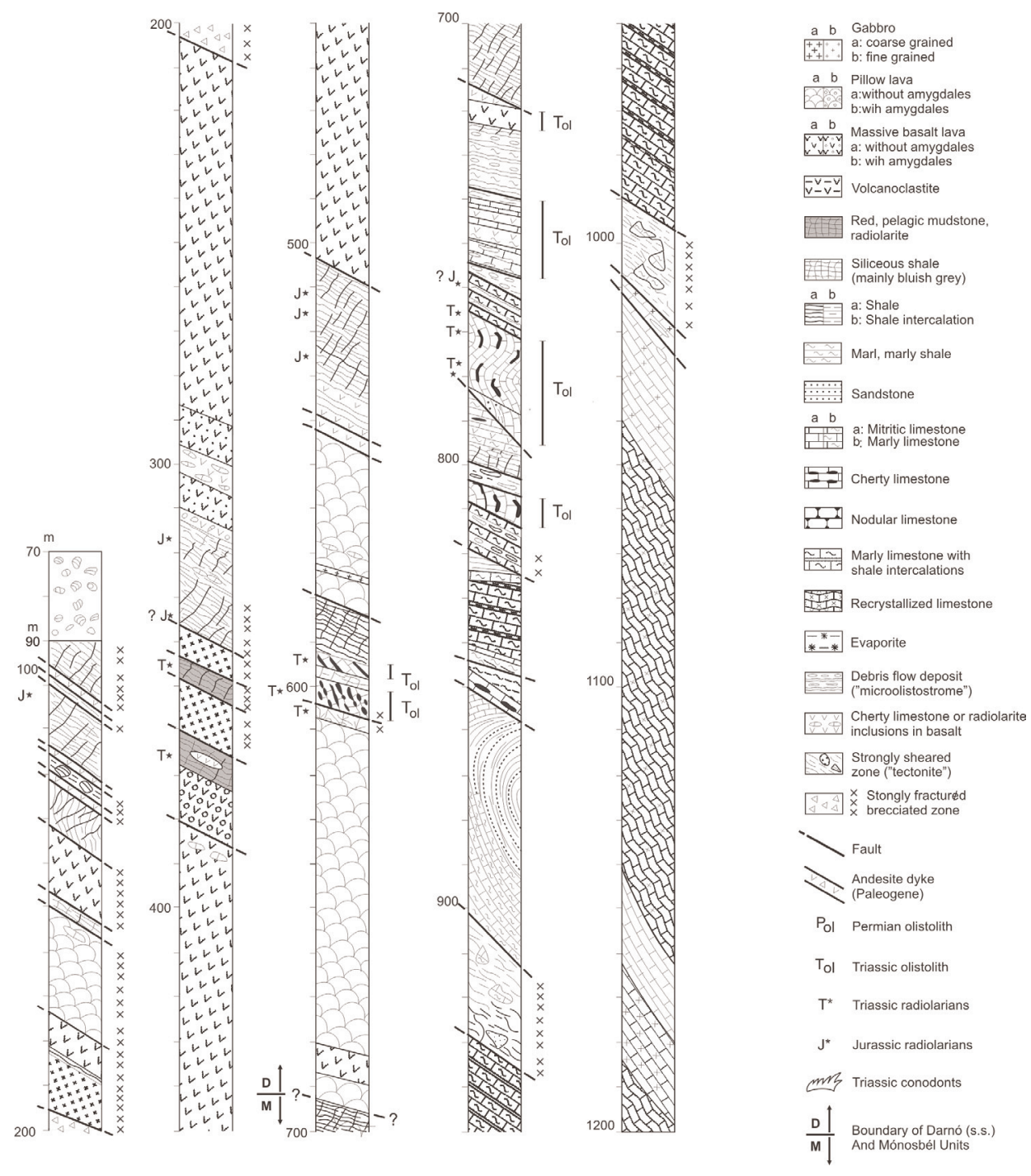

Fig. 3

Cored section of borehole Rm-131, with legend 
hyaloclastite breccia with pillow fragments. This type of basalt can be interpreted as advanced rift-type; accordingly it is probably of Middle Triassic age. The other type of basalt is of greenish color and does not contain calcite amygdals and carbonate mudstone inclusions (Fig. 6a). Its appearance is similar to that of the Szarvaskő Complex. It is probably Jurassic in age, as supported by a single

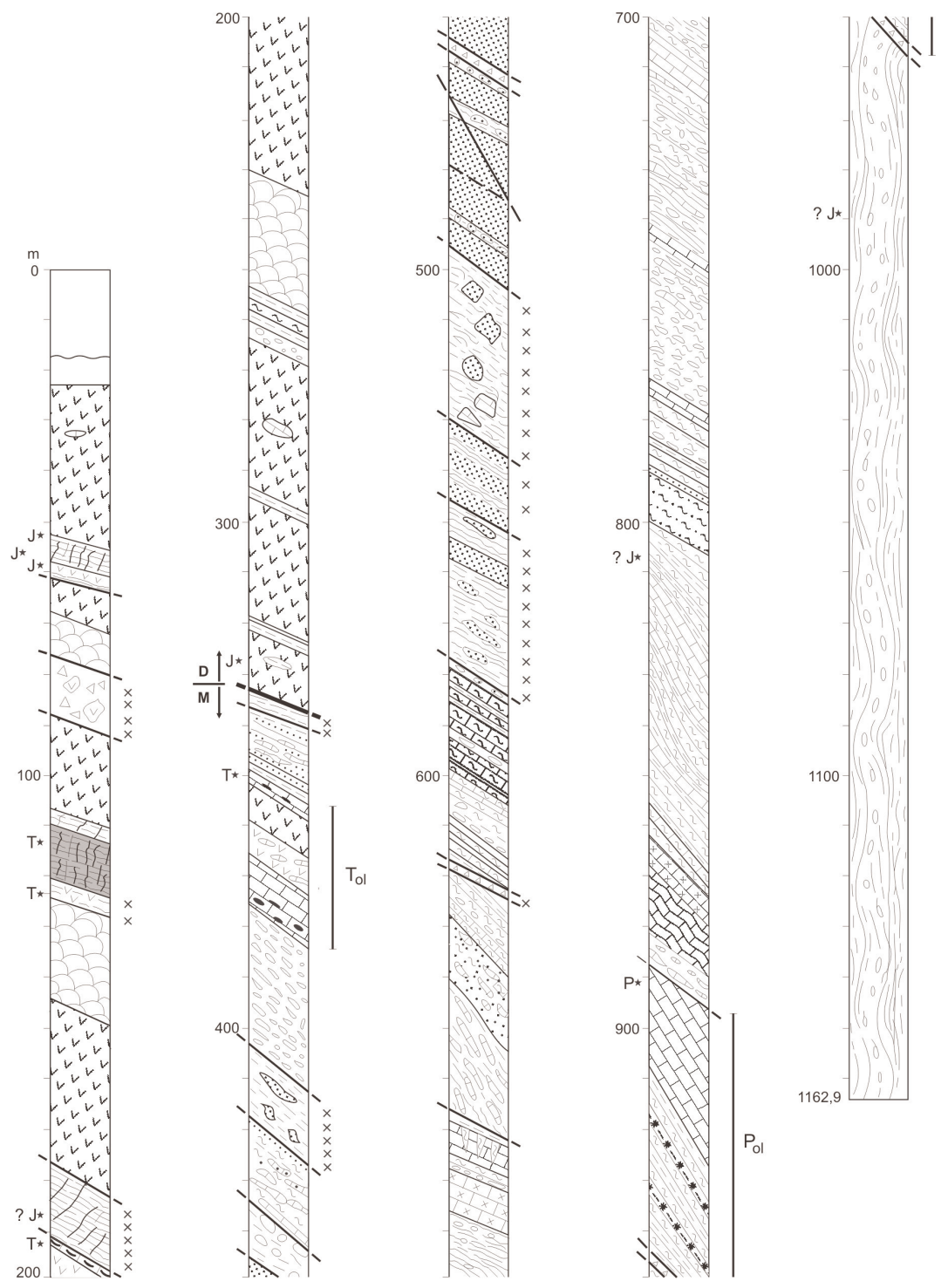

Fig. 4

Cored section of borehole Rm-136. (For legend see Fig. 3) 

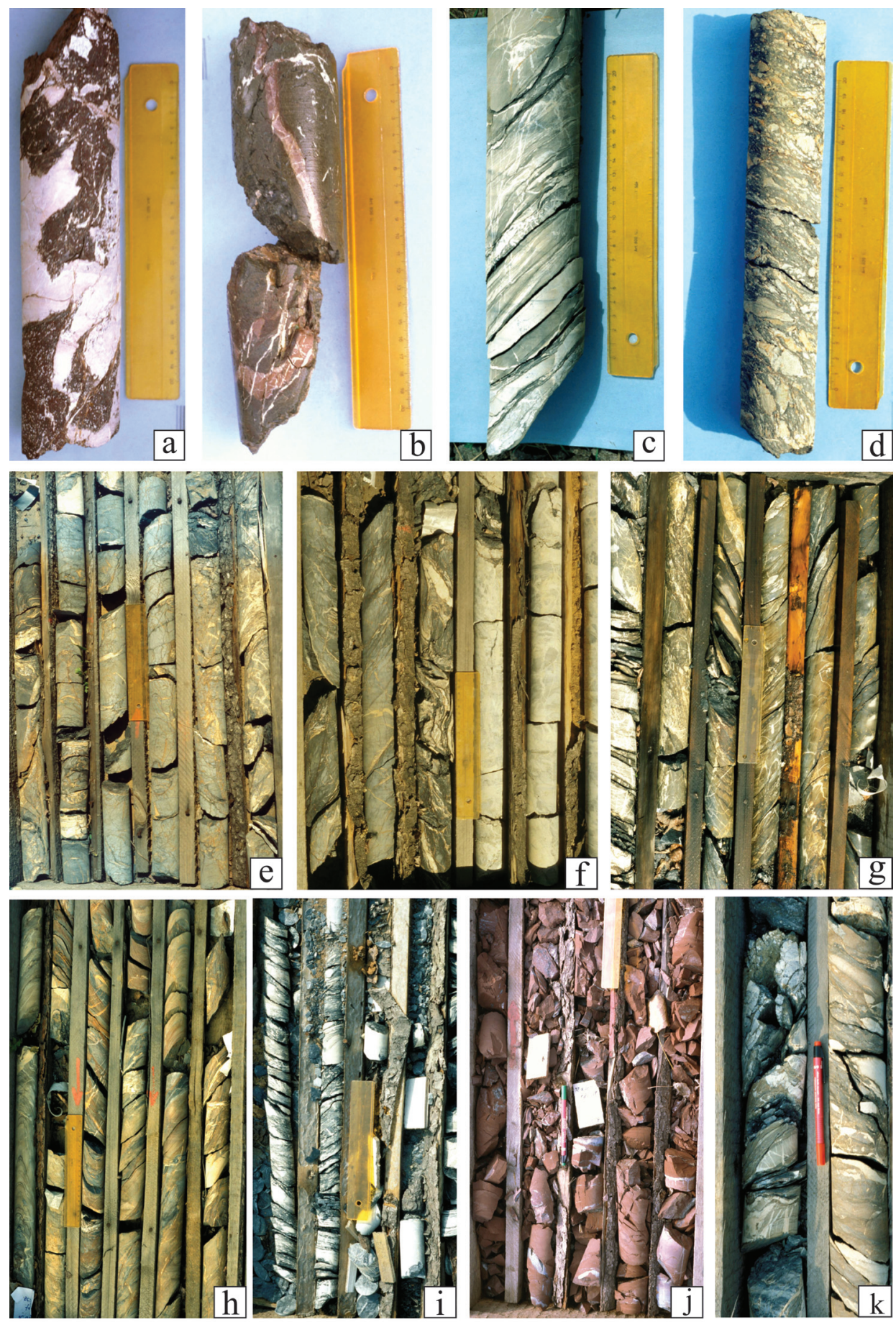

Central European Geology 53, 2010 
Bathonian radiolarian date from a black siliceous shale inclusion in doleritic basalt in a core from the Rm-136 borehole, at 329.0 m (Dosztály, in Józsa et al. 1996, section on Rm-136). According to our observations in some exposures (e.g. Hosszú-völgy Quarry, Mélyvölgy Quarry, Reszél-tető Quarry), there are smaller or larger basalt blocks which are incorporated within deep-sea deposits (Fig. $6 \mathrm{c}-\mathrm{f})$. Accordingly, the rock association penetrated by the aforementioned boreholes represents an accretionary mélange complex. Ultramafic rocks are not preserved, but the former presence of a higher, ultramafic sheet is indicated by serpentinite pebbles in the Lower Miocene Darnó Conglomerate, and by serpentinite grains in Lower Miocene sandstones north of the Darnó area (Sztanó and Józsa 1996).

\section{Similar rock assemblages in the Inner Dinarides and Inner Hellenides}

The Jurassic mélange complex of Darnó Hill, with only $7 \mathrm{~km}^{2}$ of surface extent, represents a minor displaced fragment of similar rock assemblages, widely present in the Inner Dinarides and Inner Hellenides. In the present paper a few localities will be briefly presented that were involved in our international cooperation project. All of these localities belong to the western ophiolite belt of the Balkan Peninsula (see Fig. 1), for which we employ the composite term "Maliak (Greece; Ferriére 1976; Jacobshagen 1986) - Mirdita (Albania; Shallo 1991) - Dinaridic Ophiolite Belt (Serbia and Bosnia; Dimitrijević et al. 1997; Karamata et al. 2000) - Kalnik (Zagorje region, Croatia; Pamić 1997) Zone", applying the most commonly used terms for its various sectors in different countries.

$\leftarrow$ Fig. 5

a) Core Rm-136, 364.15-364.40 m: Red, amygdaloidal basalt and white, thermally recrystallized limestone (originally soft calcareous mud, intermixed with basalt during lava flow)

b) Core Rm-136, 161.00-161.20 m: Red, micritic limestone inter-pillow void filling in green basalt

c) Core Rm-136, $862.40-862.50 \mathrm{~m}$ : Thin grey, micritic limestone (distal-type) turbidites, alternating with dark grey claystone layers representing the pelagic basin deposit

d) Core Rm-136, 887.30-887.70 m: Debris flow deposit ("micro-olistostrome"): sandstone and marly limestone clasts in dark grey claystone matrix

e) Core Rm-136, 796.8-802.8 m: Bluish-grey siliceous shale in situ ("autochthonous") deposit, with associated carbonate turbidites (partly transformed into slump structures) on the left and right sides f) Core Rm-136, 808.6-813.4 m: Dark grey shaly claystone (partly silicified, on the left) and light grey, thick bedded, brecciated limestone (likely an olistothrymma?, on the right)

g) Core Rm-136, 629.6-624.3 m: Alternating dark-grey shale and grey, marly limestone, showing all transitions between turbidite, slump and debris flow phenomena

h) Core Rm-136, 865.3-871.2 m: Dark-grey shaly claystone (mainly left) and grey marly limestone (mainly right), alternating with each other in a turbiditic succession

i) Core Rm-136, "box No. 211" (ca. 1138-1144 m; depth indications lost): cm-bedded grey limestone turbidites alternating with thin dark grey marl-shale layers (left), developed partly into debris flow deposits (2nd row from left)

j) Core Rm-136, 119.8-124.8 m: Triassic red, pelagic claystone, with cm-thick greenish grey bands k) Core Rm-136, between 428.3-431.6 m (detail): Characteristic debris flow deposit with dark-grey shaly claystone matrix and grey, marly limestone clasts 
214 S. Kovács et al.
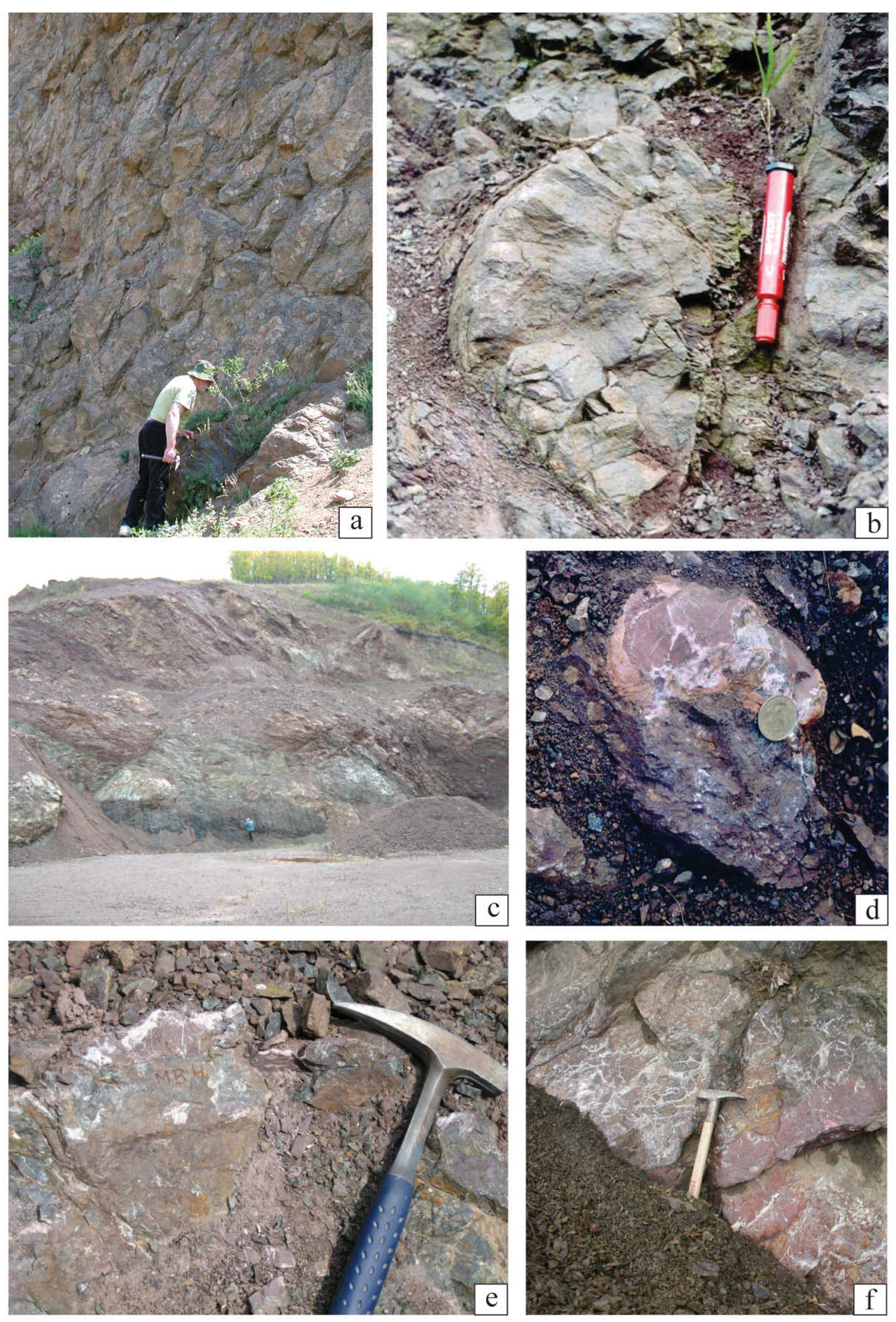

Central European Geology 53, 2010 
Although there is a rich literature dealing with the ophiolite zones of the Balkan Peninsula, mostly concerned with the ophiolite petrology and various plate tectonic reconstructions, this is the first summary focusing on occurrences investigated thus far of Triassic advanced rift-type basalt and associated deep-sea sediments, which yielded biochronological constraints on their age. Preliminary comparative observations, data and photo documentation are presented below.

\section{Zagorje region (NW Croatia)}

A rock assemblage akin to that of the Darnó Hill complex occurs over a larger surface extent in NW Croatia, in the ophiolite-bearing mélanges of the Kalnik and Medvednica Mts (see Figs 1, 7), belonging to the southwestern part of the "Zagorje-Mid-Transdanubian" zone (Pamić and Tomljenović 1998) or the "Zagorje-Bükk-Meliata" unit (Pamić 2003).

Advanced rift-type basalt in the mélange of the Kalnik Mts is best exposed in the large Hruškovec quarry, where green pillow basalt is associated with purplish red peperitic amygdaloidal basalt, containing $\mathrm{cm}$ to $\mathrm{dm}$-sized red or reddish micritic limestone inclusions (Fig. 8). The latter often shows only weak metamorphism and conodont fragments provided evidence that the age of submarine volcanism could not be younger than Triassic (Palinkaš et al. 2000). A section in the middle part of the quarry was investigated in detail by Gorican et al. (2005), which allowed a more precise dating of the complex. In the middle part of the section, from a red radiolarite-shale intercalation within pillow basalt, Late Ladinian radiolarians were reported (Muelleritortis cf. cochleata, Pseudostylosphaera imperspicua, etc.). On the other hand, a sheared horizon between olistostrome and pillow lava in the lower part of the quarry yielded Late Bajocian to Callovian radiolarians (Eucyrtidiellum semifactum, Striatojaponocapsa plicarum, etc.), thus providing age constraint on the formation of the entire mélange complex in the Middle Jurassic. The peperitic pillow facies with limestone inclusions represents the peripheral part of a basaltic submarine volcano. The quarry also exposed the central, coherent pillow facies, as well as closely packed pillow, pseudopillow and

$\leftarrow$ Fig. 6

a) green pillow basalt without calcite amygdals and any sign of contamination by calcareous mud sediment. Nagy-Rézoldal quarry

b) Ladinian red radiolarite-claystone intercalation within green basalt. Hosszú-völgy quarry

c) Olistostrome/mélange with reddish-grey to dark-grey, sometimes black siliceous shale matrix and with blocks of peperitic basalt. The latter are intersected by calcitic veins, oriented approximately perpendicular to the schistosity of matrix. Mély-völgy quarry, NW of Sirok village, central to right part of the lower yard

d) Peperitic basalt pillow at the entrance of Mély-völgy quarry

e) Light-red micritic limestone fragment in peperitic basalt. Yard of Mély-völgy quarry, in situ block at the creek, left behind during exploitation. (Photo: H.-J. Gawlick)

f) Light-red micritic limestone fragment incorporated into peperitic basalt. Reszél-tető quarry, N of Egerbakta village, westernmost part of Bükk Mts 


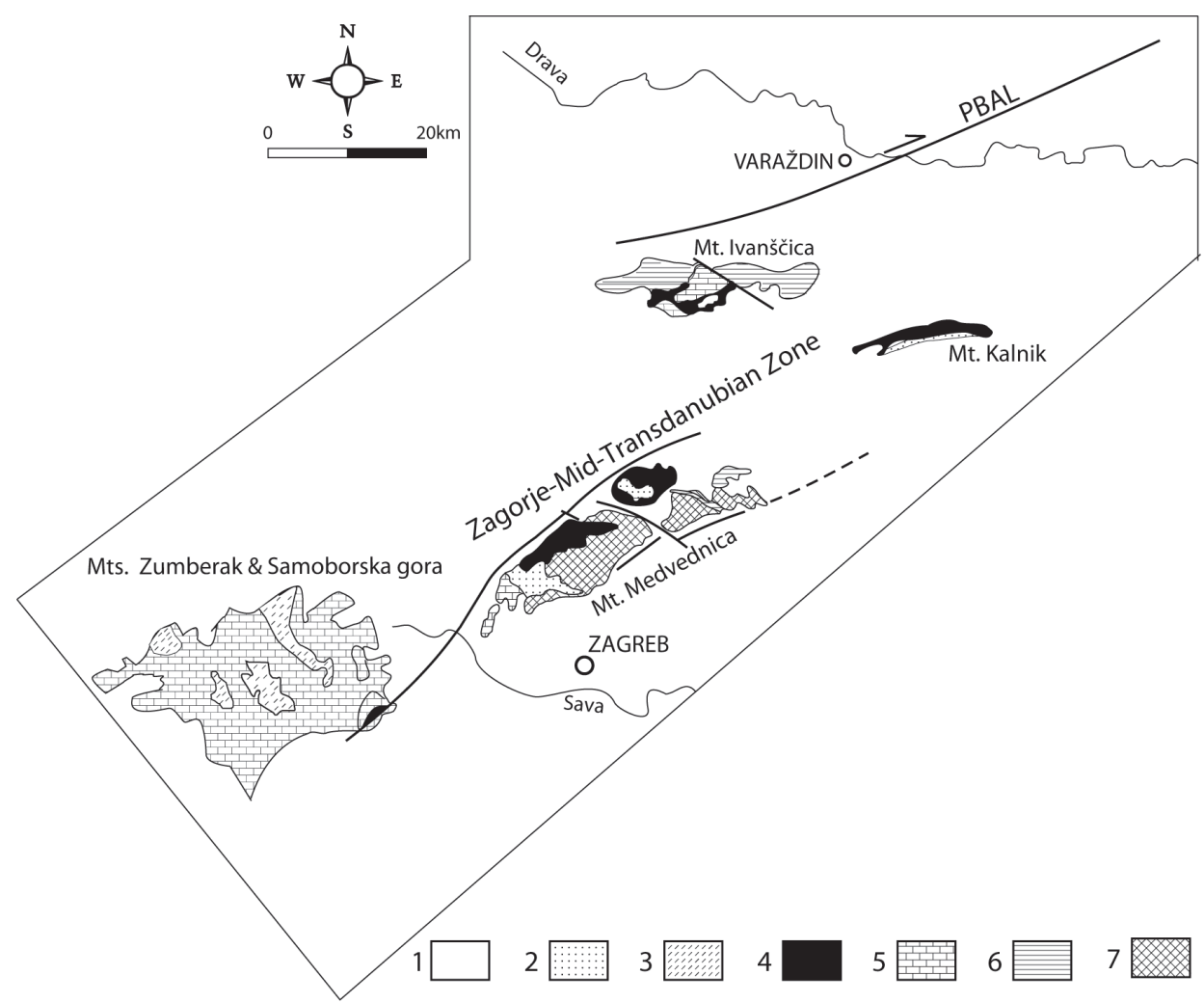

Fig. 7

Tectonic sketch of the Zagorje region, NW Croatia (Loc. 2 in Fig. 1) (after Halamic et al., 2001, slightly modified). 1. Neogene and Quaternary fill of the Pannonian Basin; 2. Late Cretaceous-Paleocene flysch; 3 . Hauterivian to Cenomanian pelagic limestone and calcareous turbidites; 4 . Ophiolitic mélange (discussed in the present paper); 5. Late Triassic platform facies; 6. Late Paleozoic and Triassic siliciclastics and carbonates, with associated Triassic volcanics; 7. Paleozoic-Triassic metamorphic Medvednica Complex PBAL - Periadriatic-Balaton Lineament

Fig. $8 \rightarrow$

All pictures are from the Hruškovec quarry, Kalnik Mts., NW Croatia:

a) Panoramic view from the central part of Hruškovec quarry, Kalnik Mts., NW Croatia: green and red basalt blocks in black shale/siliceous shale matrix (best visible at the right margin of the photo)

b) Red micritic limestone fracture filling network in "brecciated" peperitic basalt.

c) Red micritic limestone inclusions (with thermally altered crusts) in "fine-brecciated" peperitic basalt d) Green basalt, with hyaloclastite between the pillows

e) Red micritic limestone clasts in dark greenish gray basalt

Central European Geology 53, 2010 

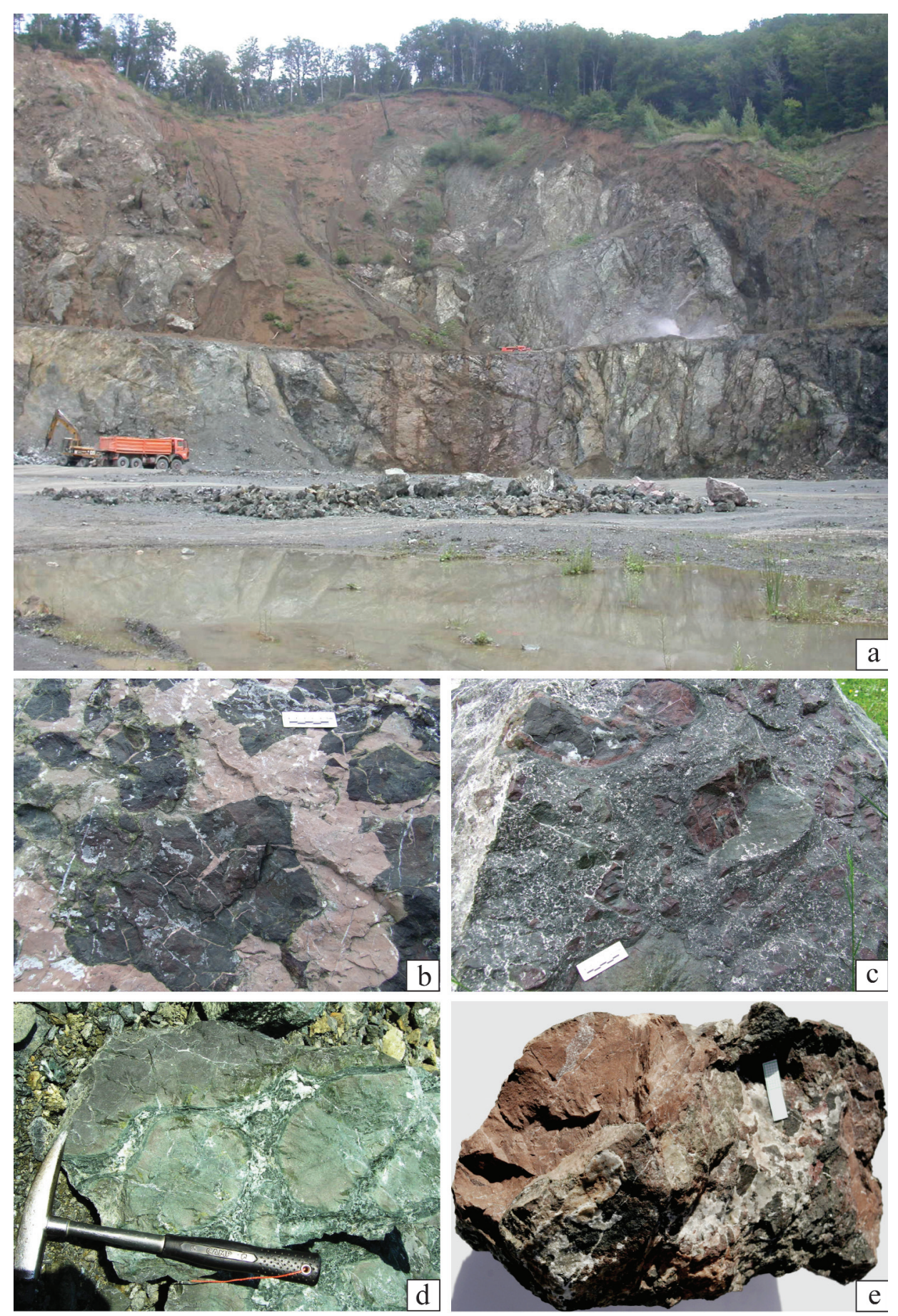

Central European Geology 53, 2010 
hyaloclastite breccia facies (Palinkaš et al. 1998; Borojević et al. 2000; Palinkaš et al. 2008).

Other localities in the Kalnik Mts, where siliceous sediments are associated with pillow basalt, yielded Early Ladinian to Middle Norian radiolarian faunas. At the Hrastov brijeg locality red radiolarite occurs between brownish-green and greenish pillow lavas (however, the contact between the sediment and basalt is either covered or visibly tectonic), which yielded late Early Ladinian radiolarians (Oertlispongus inaequispinosus, Falcispongus calcaneum, Baumgartneria ambigua, etc.). On the other hand, in the Jazvina quarry, silicified reddish radiolarian limestone and greenish-gray radiolarian chert overlying pillow lavas contain Late Carnian to Middle Norian radiolarians (Capnuchosphaera spp, Capnodoce sp., Whalenella sp., etc.). In the Kestenik road-cut section, in the eastern part of the mountains, red radiolarite and greenish siliceous shale are exposed between underlying pillow lava (ophitic metabasalt) and overlying amygdaloidal lava with $\mathrm{cm}$-sized red shale enclaves. The radiolarite contains Middle to Late Carnian radiolarians (Capnuchosphaera triassica, Spongostylus carnicus, Nakasekoellus sp., etc.).

In the northwestern part of the Medvednica Mts, in the Oresje quarry, pillow lavas with red micritic limestone inclusions are exposed, representing typical peperitic facies (for details see Halamić et al. 1997). Conodonts (Paragondolella cf. excelsa) found in the limestone parts indicate a Late Anisian to Early Ladinian age. In the nearby Poljanica creek valley, isolated red radiolarite blocks occur, which yielded Late Ladinian to Late Carnian radiolarians (Halamić and Gorican 1995).

\section{Vareš region, Central Bosnia}

The peperitic pillow basalt facies near Vareš is a part of the "Borovica-VarešCevjanovici-Kalinovik Zone" (Pamić 1963; Karamata et al. 2000), a narrow thrust sheet between the Bosnian Flysch Zone to the SW and the Dinaridic Ophiolite Belt to the NE, consisting of Upper Permian and Lower to Middle Triassic formations (Figs 1,9). The best exposure of basaltic rocks can be found at the Smreka quarry north of Vareš. Here, closely-packed pillow and hyaloclastitebreccia pillow facies are exposed, and both contain peperite with reddish limestone inclusions (Kiss et al. in press). In this area the peperitic pillow basalt can be followed over a distance of several $\mathrm{km}$ along a NW-trending belt tectonically bounded by Lower Triassic formations on both sides. The thickness of basaltic unit is approximately $500 \mathrm{~m}$. Laterally it is intercalated with Ladinian chert and cherty limestone. Jurassic ophiolite olistoliths of the Dinaridic Ophiolite Mélange also crop out in the vicinity of the Smreka quarry; they are clearly distinguishable from the Triassic submarine basaltic rocks on the basis of their different textural features (there are less amygdales in it, they are more compact and glassy and contain more hyaloclastite breccia) and lack of limestone-bearing peperitic basalt. 
Zlatar and Zlatibor Mountains, SW Serbia

Two occurrences, both of them belonging to the Dinaridic Ophiolite Belt, were involved in our comparative studies (see Figs 1, 10).

Along the road from Bistrica to Priboj, an approximately $40 \mathrm{~m}$-large slide block (first described by Popević 1970 ) is exposed within the olistostrome/mélange (Fig. 11a-e). It is made up predominantly of reddish amygdaloidal basalt and its hyaloclastics and breccia (about $30 \mathrm{~m}$ in thickness), overlain by reddish, cherty, Bódvalenke-type limestone (about $8 \mathrm{~m}$ thick). From the latte, an Early Ladinian radiolarian association (with Oertlispongus inaequispinosus, Pseudostylosphaera japonica and Triassistephanidium laticornis) was described by Obradović and Gorican (1988).

Along the road from Gostilje to Sirogojno descending to the Katusnica stream, in the road curve before the stream, greenish pillow basalt is exposed (Fig. 11f-h). It is associated with reddish, Bódvalenke-type limestone, and red chert intercalations, which yielded Carnian radiolarians (Dosztály, unpubl. data).

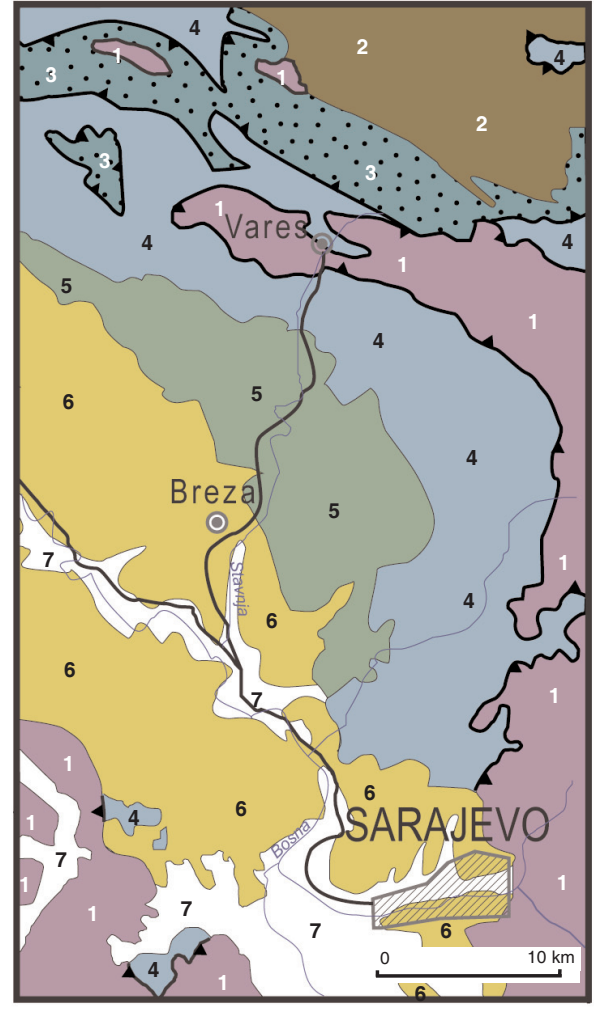

Fig. 9

Geologic setting of the Vareš region (based on the Geological Map of Yugoslavia, 1:500 000). 1. Triassic rocks (undifferentiated); 2. Ultramafics and their metamorphic soles; 3 . "Diabase-Chert Formation" (=ophiolitic mélange); 4. Jurassic to Lower Cretaceous siliciclastic and calcareous formations of the Bosnian Flysch Zone; 5. Upper Cretaceous Formations of the Bosnian Flysch Zone; 6. Miocene deposits; 7. Quarternary

\section{Mirdita Zone, Albania}

Although the Mirdita Zone of Albania was not included in our comparative studies, the occurrence of Triassic pillow basalts representing the Neotethyan advanced rift stage should be mentioned. The associated radiolarite has been dated by Ladinian to Carnian radiolarians (Marcucci et al. 1994; Chiari et al. 1996; Gawlick et al. 2008). Amygdaloidal basalt and Bódvalenke-type limestone are also present in the accretionary mélange (Gawlick, pers. comm.). 


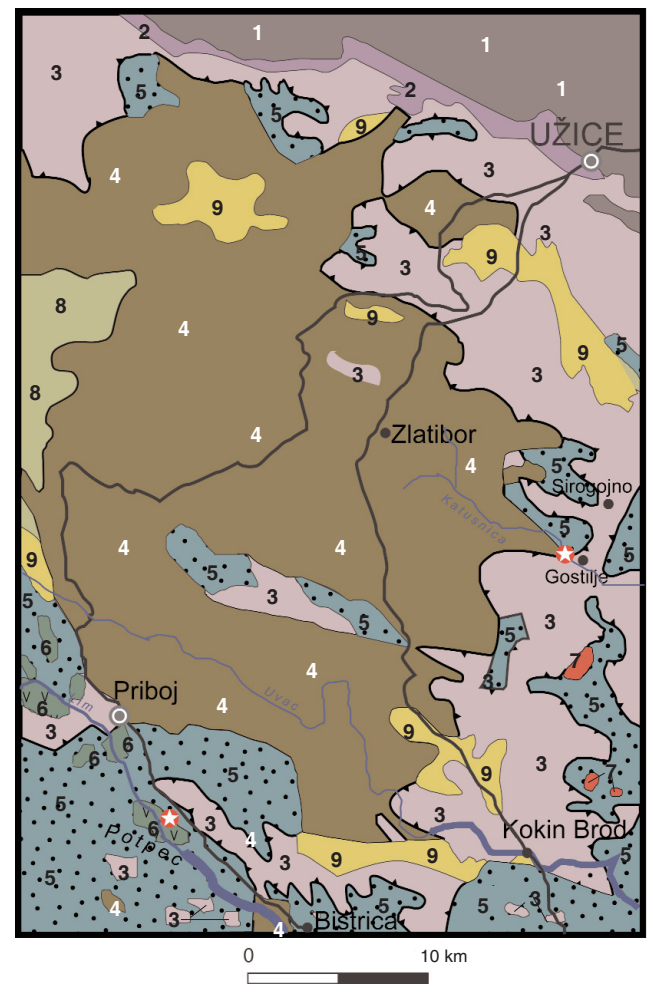

Fig. 10

Geologic map of the Zlatibor - northern Zlatar area, SW Serbia, with locations of the studied outcrops: locality of Potpec along the Bistrica-Priboj road and locality in the valley of Katušnica Creek, near Gostilje (based on the Geological Map of Yugoslavia, 1:500 000). 1. Drina-Ivanjica Paleozoic; 2. Lower Triassic mixed calcareous-siliciclastic deposits ("Werfen Group"); 3. Middle-Upper Triassic platform carbonates; 5. ultramafics and their metamorphic soles; 6. "Diabase-Chert Formation" (=ophiolitic mélange); 7. basic rock bodies in the mélange (gabbro, pillow basalt); 7. granitoid bodies in the mélange; 8. Upper Cretaceous carbonates; 9. Neogene formations; asterisks mark the studied outcrops

Fig. $11 \rightarrow$

Basalt - "Bódvalenke-type" limestone olistothrymma in the olistostrome/mélange of the Dinaridic Ophiolite Belt, locality of Potpec, exposure along the road leading from Bistrica to Priboj, SW Serbia. Note: Similar "Bódvalenke-type" limestone + amygdaloidal basalt slide blocks (=olistothrymmata) could have been encountered by the Darnó Hill boreholes in the Mónosbél Unit:

a) Panoramic view of the upper, "Bódvalenke-type" limestone part of the slide block described in the text, exposed on the southwestern side of the road. The olistostrome/mélange, containing sandstone and basalt olistoliths, above the basalt-limestone block, can be seen on the left

b) The contact between the lower part of limestone and the underlying basalt

c) The contact between the lowermost part of the thin-bedded limestone and the uppermost part of fragmented basalt with weathered hyaloclastite matrix

d) Purplish-red, in part amygdaloidal basalt fragments in hyaloclastite matrix, exposed on the opposite (northeastern) side of the road

e) The olistostrome (less sheared) beneath the basalt+limestone olistothrymma, with shale matrix and sandstone olistoliths. Opposite (northeastern) side of the road leading from Bistrica to Priboj

f) Red basalt with intercalation of "Bódvalenke-type" red cherty limestone (in the middle), which yielded Carnian radiolarians (Dosztály, unpubl. data). Zlatibor Mts., along the road leading from Sirogojno to Gostilje, in the curve $300 \mathrm{~m}$ after Katušnica Creek

g) Green basalt (on the right) with m-sized block of "Bódvalenke-type" limestone. Locality: the same as of Fig. 11f)

h) Enlarged Bódvalenke-type" limestone block from Fig. 11g

Central European Geology 53, 2010 
Neotethyan accretionary complexes, Darnó, Dinarides, Hellenides 221
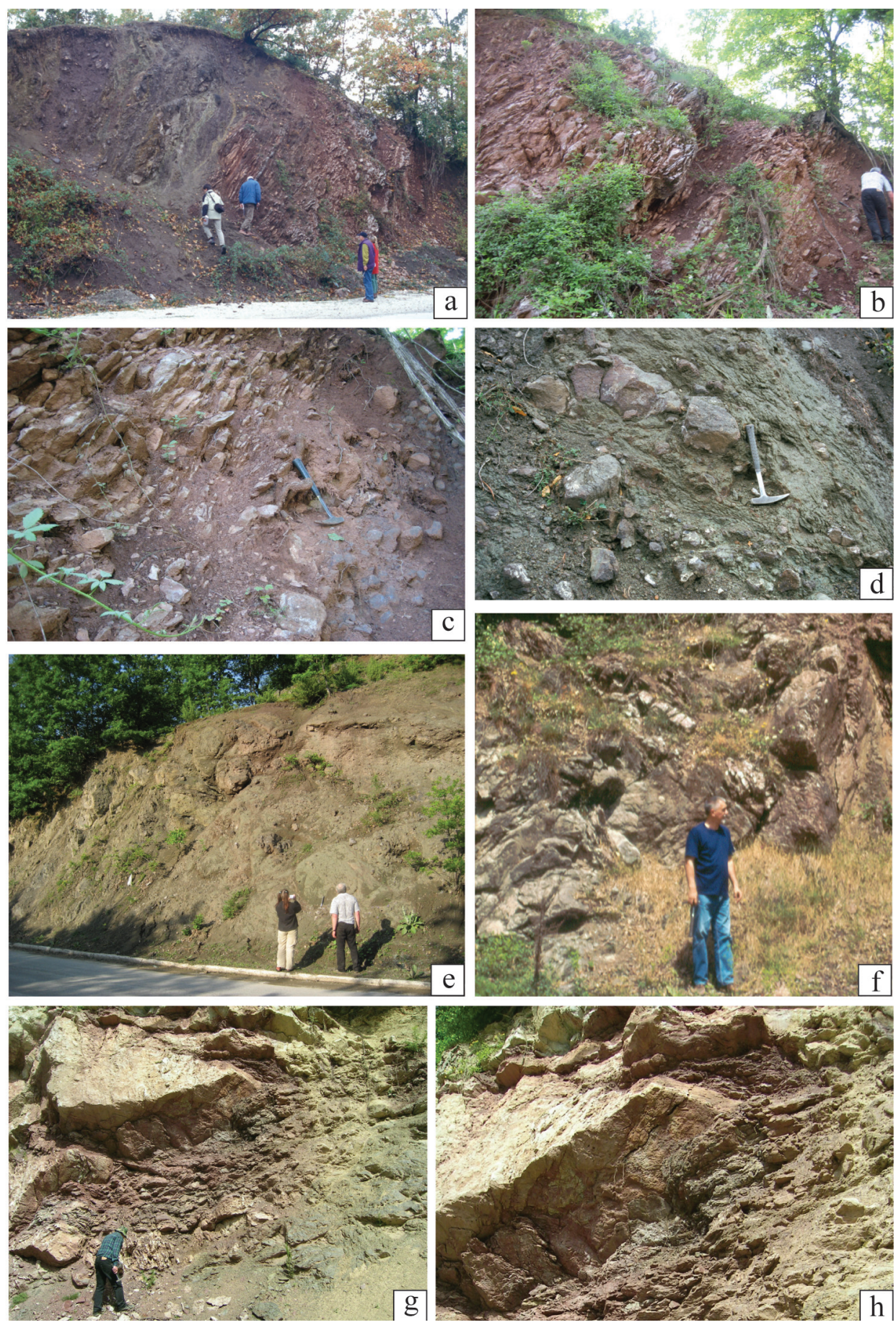

Central European Geology 53, 2010 


\section{Northern and Central Greece}

\section{Northern Pindos Mountains}

In the northern part of the Pindos Mountains, in the Pindos Zone s.s., the following tectono-stratigraphic units are distinguished: 1 . Triassic rift-related basalts and sediments within tectonic-sedimentary mélange (Avdella Mélange in the northern Pindos Mountains: Jones and Robertson 1991; Kemp and McCaig 1984; Pe-Piper 1998; Saccani et al. 2003; Loggitsion Unit in the Othrys Mountains: Ferrière 1982); 2. Middle Jurassic MORB-type and ophiolitic sequences (Dramala Complex in the northern Pindos Mountains: e.g. Capedri et al. 1980; Jones and Robertson 1991; Metallion, Fourka and also some other units in the Othrys Mountains: Ferrière 1982); 3. Mesozoic pelagic, platform-related sedimentary sequences and turbiditic slope sediments (Dio Dendra Group in the northern Pindos Mountains: Kemp and McCaig 1984; Jones and Robertson 1991; but no equivalent formation exists in the Othrys Mountains), 4. Upper Cretaceous platform carbonates (Orliakas group in Northern Pindos Mountains: Jones and Robertson 1991); 5. Uppermost Cretaceous-Eocene flysch (Pindos Flysch in the Northern Pindos Mountains: Richter 1976 (the latter two are not distinguished on the geologic map of Othrys by Ferrière (1982).

The mélange is best exposed in the area of the small villages of Avdella and Perivoli, W of Ziakas (=Avdella Mélange; Jones and Robertson 1991). The studied localities are shown in Fig. 12; typical physiography of this area is presented in

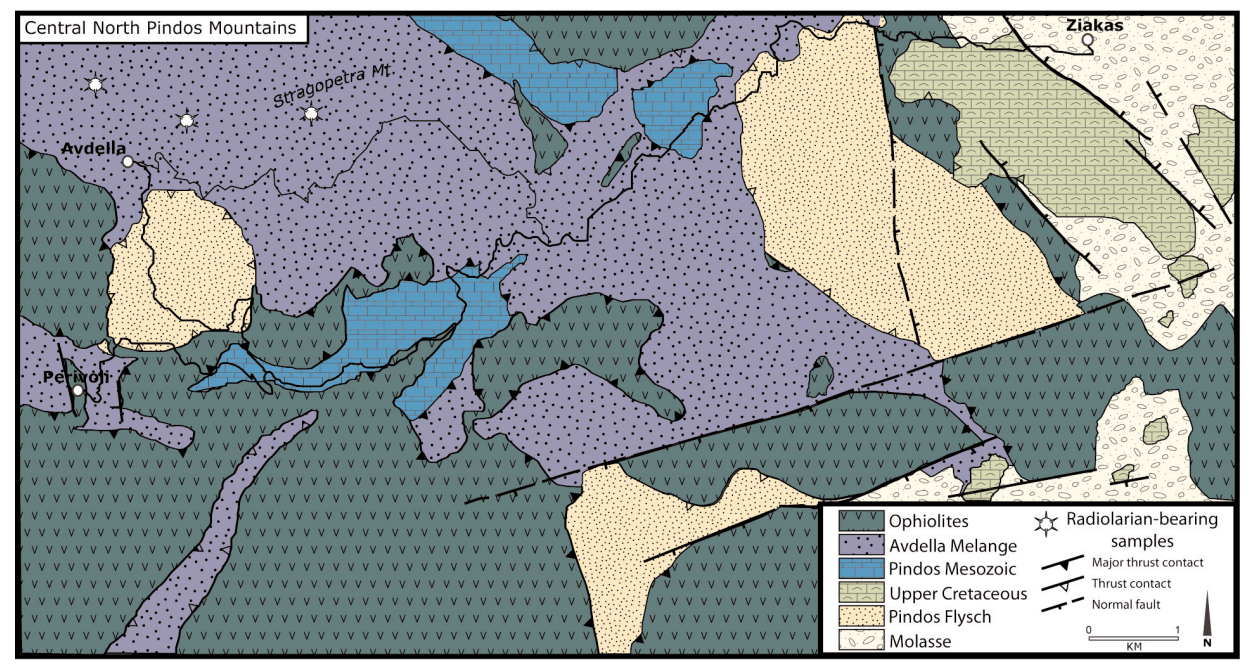

Fig. 12

Geological sketch map of the central part of Northern Pindos Mountains (area between Avdella Perivoli - Ziakas villages, W of Grevena town), after Jones \& Robertson, 1991, slightly modified. Localities discussed in the text: NE of Avdella, opposite side of Avdella valley; SE-ward extension of Straggopetra Mt., incl. Lekani Mt.; NW of Avdella, along the forestry road encircling the Avdella valley 
Fig. 13a. Samples for radiolarians were collected by S. Kovács and V. Tselepidis in 1993 and 1995, and were first studied by L. Dosztály (results were mentioned first in Skourtsis-Coroneou et al. 1995); results of the new investigations are presented by Ozsvárt et al. (in press).

In a small gorge in the northeastern vicinity of Avdella village the mélange is exposed with black shale matrix and blocks of reddish and greenish basalt and subordinate red limestone. In a large block on the northwestern side of the gorge, green pillow basalt overlain by red radiolarite is exposed in a thickness of about 6-7 m. The age of the radiolarite is Anisian-Carnian (Dosztály 1995; unpublished list of determination (Ozsvárt et al., in press). The sample taken from the immediate cover of the basalt yielded the oldest radiolarian assemblage, which indicates a Middle Triassic age (Late Anisian, probably Early Illyrian), giving an upper age limit of the basalt. Characteristic amygdaloidal structure was found in another pillow basalt block exposed along the road $30 \mathrm{~m}$ SE of the gorge.

Another outcrop NW of Avdella (see Fig. 12), along the forestry road encircling the Avdella Valley, exposes a sheared red radiolarite - red, micritic limestone horizon between two basalt blocks, that yielded Middle Triassic (IllyrianLongobardian) radiolarians (Ozsvárt et al., in press).

On the southeastern extension of Stragopetra Mountain (1,570 m above sea level) amygdaloidal pillow basalts are widely exposed, in a thickness of approximately $300 \mathrm{~m}$. In one horizon pinkish or reddish Hallstatt-type micritic limestone slide blocks occur. From one of these blocks Migiros and Tselepidis (1991) described a Late Scythian ammonoid fauna, and S. Kovács identified the conodont Gondolella regale, pointing to earliest Anisian age (sample collected by V. Tselepidis). Typical peperitic rocks with a mixture of purplish-red and green basalt and with the lime mud still in unlithified state is characteristic for this horizon. Kiss et al. (in press) pointed out that geochemical characteristics of the basalt suggest their intra-plate origin. The basalt succession is overlain by red radiolarite toward the SE (Lekani Mountain), yielding Middle Triassic (Anisian? Ladinian) and Upper Triassic (Carnian) radiolarians, suggesting an Anisian age of the pillow lavas for the most part (biostratigraphic details in Ozsvárt et al., in press).

In a road curve $\mathrm{W}$ of Ziakas, before the branching off of the road leading to Avdella, greenish-reddish amygdaloidal basalt is exposed, containing a m-sized red, micritic limestone inclusion ("olistolith") and several small, cm-sized ones (Fig. 13. c-e).

Slide blocks of Bódvalenke-type reddish, thin-bedded limestone with abundant red chert interlayers are also characteristic constituents of the Avdella Mélange (Fig. 13b). 

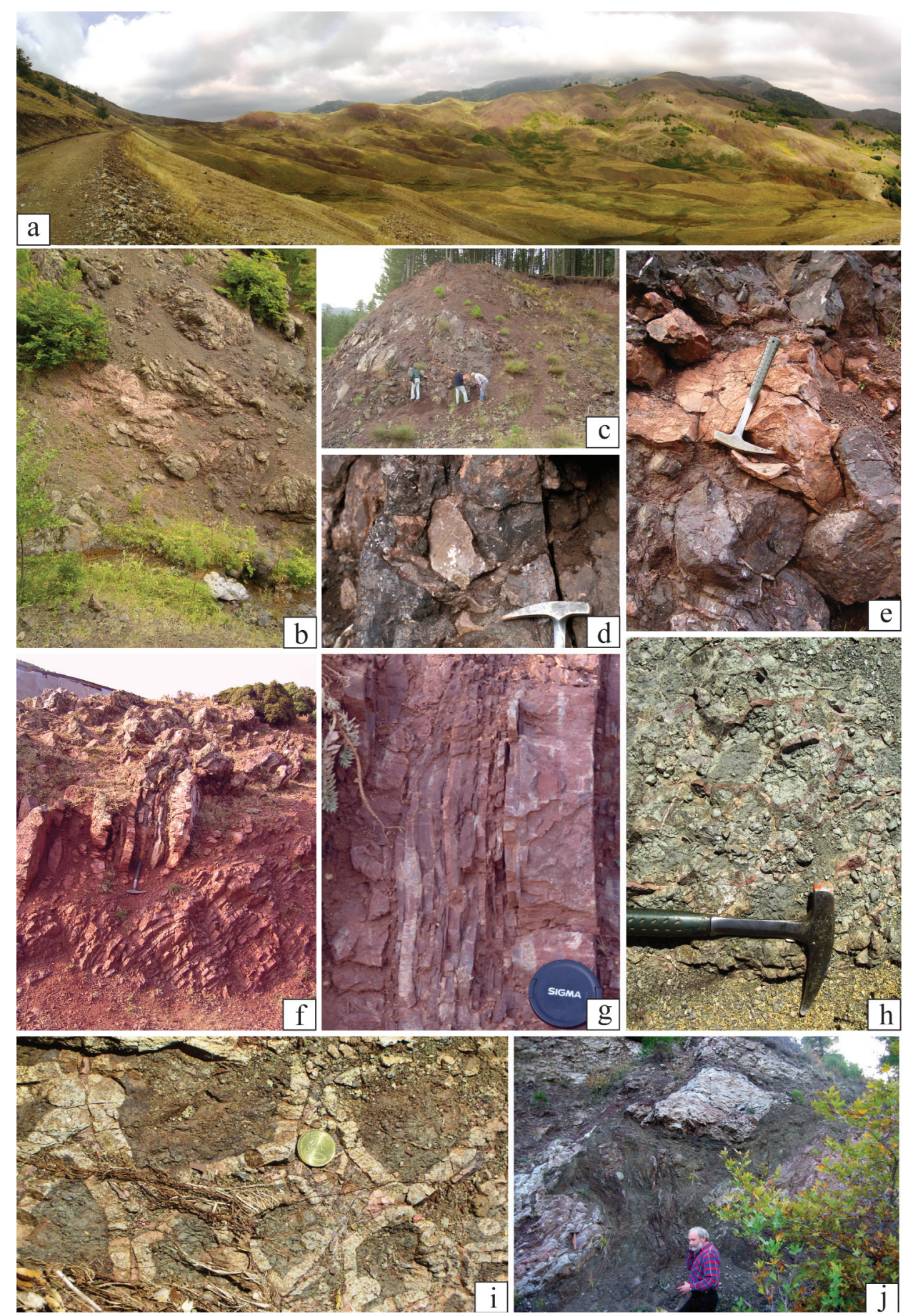

Central European Geology 53, 2010 


\section{Othrys Mountains and Euboea Island}

The western and central parts of the Othrys Mountains are built up by the ophiolitic Loggitsion Unit (Ferrière 1982) containing all members of an ideal ophiolite suite (from ultramafics to pillow lavas) and associated sediments (shale, sandstone, cherty limestone, radiolarite), usually as large blocks in the mélange (Fig. 14). Of main interest for correlation with the Darnó Hill complex (G. Migiros and V. Tselepidis directed the attention of Hungarian workers to this) are the widespread occurrences of Triassic amygdaloidal basalt (often with peperitic facies), red radiolarite (Ozsvárt et al., in press) and reddish, siliceous Bódvalenketype limestone (Fig. 13f-g). Middle Triassic (probably Illyrian) radiolarian fauna was found (Ozsvárt et al., in press) in a small red radiolarite outcrop above the basalt, about $10 \mathrm{~km}$ SSE of Metallion, along the road leading to Lamia (Fig. 13h-i).

The same mélange continues southeastward to Euboea Island; it was described by Danielan and Robertson (2001) as "Pagondas Mélange", also containing, among other things, blocks of reddish, amygdaloidal basalt and Bódvalenke-type limestone (Fig. 13j).

This oceanic zone was named by Ferrière (1976) as the "Maliak Zone" after Maliak Bay (see also in Jacobshagen 1986) and continues northwestward into the ophiolite mélange of the North Pindos Mountains (although partly admixed

$\leftarrow$ Fig. 13

a) Landscape of a type-area of Neotethyan accretionary mélanges: small, hill-like elevations are blocks of different rocks (basalt, ultramafics, cherty limestone, radiolarite) in red or reddish-weathered shaly matrix. Panoramic view $\mathrm{N}$ of Avdella, made from the forestry road encircling the head of the valley around the village. Note: The wells drilled on Darnó Hill, NE Hungary, could have penetrated a similar rock association - but was only seen in cores

b) "Bódvalenke-type" red, cherty limestone within pillow basalt; some matrix of the mélange is visible in the middle part at the right margin of the photo. E of Avdella village, cut of a small creek

c) Large, red micritic limestone inclusion (in the middle) in reddish-greenish, amygdaloidal pillow basalt. Road curve W of Ziakas, at the branching-off towards Avdella

d) Red micritic limestone inclusions in amygdaloidal basalt (road curve W of Ziakas, at the branchingoff towards Avdella)

e) Characteristic peperitic facies: light-red micritic limestone inclusions in dark purplish-red, amygdaloidal basalt (road curve $\mathrm{W}$ of Ziakas, at the branching-off towards Avdella)

f) Typical "Bódvalenke-type" limestone block exposed along the road at the northeastern edge of Anavra village, central part of the Othrys Mts., Central Greece. Folded limestone-red chert succession overthrust on a red chert horizon of the formation. Central part of the outcrop

g) Details from the outcrop: typical lithology of Bódvalenke Limestone, red chert interlayers predominating over pink or whitish, micritic limestone

h) Western part of the Othrys Mts., exposures along the main road leading from Domokos to Lamia, Loggitsion Unit. Red micritic - marly network in peperitic basalt

i) Loggitsion Unit, western part of the Othrys Mts.: Green basalt, with some black shale, then red radiolarite above it, yielding Ladinian radiolarians (described in Ozsvárt et al. in press). Along the western side of the road leading from Domokos to Lamia, $5 \mathrm{~km} \mathrm{~S}$ of Metallion village

j) Central part of Euboea Island, Pagondas Mélange (Danelian and Robertson, 2001)."Bódvalenketype" limestone blocks (with abundant red chert layers) and red chert fragments in sheared black shale matrix. Exposure in the curve of the road leading from Chalkida, just before the branching to Nea Pagondas 


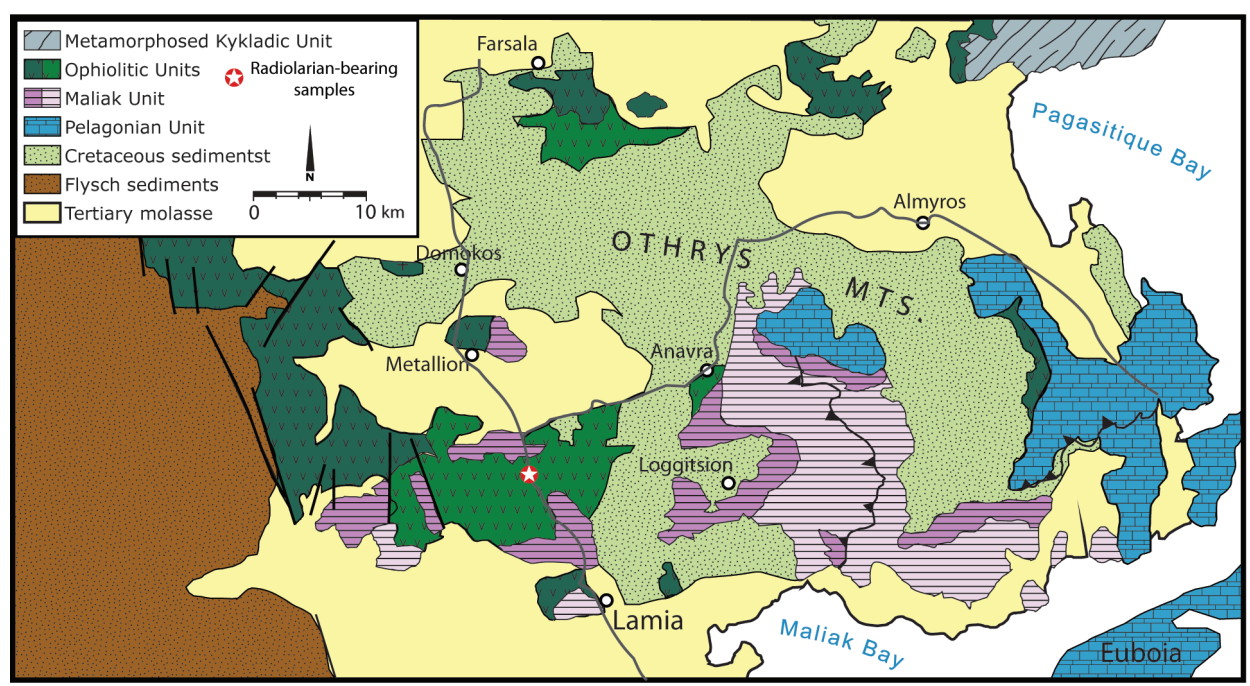

Fig. 14

Geologic sketch map of the Othrys Mts. (modified after Ferriére, 1982), with location of the studied radiolarite above basalt shown in Figure 13i (along the road between Domokos and Lamia)

there with elements of the s.s. Pindos Series, lacking any ophiolite due to Late Eocene thrusting; Papanikolaou 1986).

\section{Discussion and some conclusions}

In the present paper the main results of our recent studies and re-evaluation of the previous ones on the Mesozoic complexes of Darnó Hill are summarized. Amygdaloidal basalt and associated sediments showing features of the peperitic facies are locally typical in the upper unit; Bódvalenke-type limestone amygdaloidal basalt slide blocks were found in the lower unit. Similar rock associations were documented all along the Inner Dinarides - Inner Hellenides up to Maliak Bay in the central part of continental Greece. Dinaridic correlations of the Jurassic slope facies of the lower unit was summarized by Haas (2008) and facies relations of the Bódvalenke Limestone were discussed by Kovács (in the present volume). Preliminary results of the comparison of Triassic pelagic sedimentary rocks between Greece and Hungary were already presented by Skourtsis-Coroneou et al. (1995). Taking these works into consideration as well, some preliminary conclusions and proposals can be presented, as follows:

- Triassic, early rift-type peperitic basalt of Darnó Hill and Bódvalenke-type limestone associated with it represent the northwesternmost known occurrences of these facies, characteristic for accretionary mélanges of the western ophiolite belt of the Balkan Peninsula ("Maliak-Mirdita-Dinaridic Ophiolite Belt-Kalnik Zone"), displaced in the Mid-Hungarian Fault Zone during the Tertiary. The type 
area of the Bódvalenke Limestone Formation should also be considered in this respect; this block was displaced a few tens of $\mathrm{km}$ northeastward within the Darnó Fault Zone (cf. Less 2000). Occurrences of these facies further northward and westward (into the West Carpathians and Eastern Alps, respectively) are not known.

- A number of plate tectonic-paleogeographic models have been proposed in the last 20-30 years for the Gemer-Bükk region, involving the Mesozoic of Darnó Hill (for example, Kovács 1984). However, plate tectonic interpretations based on these small, few $\mathrm{km}^{2}$-sized and displaced Neotethyan fragments occurring in NE Hungary - SE Slovakia seem rather "ill-founded" (or even an illusion...) in the light of models based on complete cross-sections through the Neotethyan accretionary complexes of the Dinarides and Hellenides. Consequently, these models must serve as the basis of the plate tectonic/paleotectonic reconstruction of the Darnó Hill and related occurrences.

- The intimate association between the mid-Triassic basalt volcanism and pelagic carbonate sediments point to a specific, advanced rifting stage of the NeoTethys. The characteristics of coeval sedimentary facies, i.e. Hallstatt-type limestone (red micrite without chert) $\rightarrow$ Bódvalenke-type limestone (reddish micrite with abundant red chert interlayers) $\rightarrow$ red radiolarite may have been mostly controlled by the distance of the depositional area from contemporaneous carbonate shelves (the probable source areas of the lime mud fraction prior to the latest Jurassic calcareous nannoplankton "explosion"). Further detailed, comparative work will be necessary on this early rift-type basalt and associated deep-sea sediments to decipher their geodynamic significance in the early rifting stage of the Neotethys Ocean.

\section{Acknowledgements}

Field expenses and the preparation of the present contribution were supported by the National Research Fund (OTKA) in Hungary, grants No. T 47121 (Sándor Kovács, Károly Brezsnyánszky), T 49633 (Ferenc Molnár), K 61872 (János Haas, Károly Brezsnyánszky), F 48341 (Péter Ozsvárt), by the Croatian-Hungarian Technological and Scientific (TéT) Intergovernmental Cooperation (HR-17/2004 and Cro-007/2006; Ladislav Palinkaš, Ferenc Molnár) and by the scientific exchange program between the Hungarian Academy of Sciences and Serbian Academy of Sciences and Arts (project No. 5: "Terranes of Dinaridic origin in the Pannonian region"). Joint field work in Greece and Hungary in 2005 was supported from the Hungarian side by OTKA grant No. 47121. The authors are indebted to Tamás Mikes, Josip Halamic, Hazim Hrvatovic, Milan Sudar, Divna Jovanovic, Nevenka Djeric, Georgios Migiros, Dimitrios Papanikolaou and Vassilis Tselepidis for their suggestions and assistance on the field and for the very useful consultations. Zoltán Balla (Budapest) is thanked for his thorough reviewing and constructive remarks. 


\section{References}

Árkai, P., E. Árva-Sós, G. Bagoly-Árgyelán, L. Csontos, L. Dosztály, Z. Gulácsi, P. Horváth, S. Józsa, S. Kovács 1998: Neotethyan oceanic assemblages in NE Hungary: a review of present knowledge. - Carpatho-Balkan Geological Association, XVI. Congress, 1998, Vienna, Austria, Abstract volume, p. 45.

Balla, Z. 1987: Tectonics of the Bükkian (North Hungary) Mesozoic and relations to the West Carpathians and Dinarides. - Acta Geologica Hungarica, 30/3-4, pp. 257-287.

Balla, Z., Cs. Baksa, J. Földessy, L. Havas, I. Szabó 1980: The tectonic setting of the ophiolites in the Bükk Mountains (North Hungary). - Geologicky Zbornik. - Geologica Carpathica, 31/4, pp. 465-493.

Balla, Z., Cs. Baksa, J. Földessy, L. Havas, I. Szabó 1981: Mezozoós óceáni litoszféra maradványok a Bükk-hegység délnyugati részén (Mesozoic oceanic lithosphere remnants in the southwestern part of the Bükk Mountains, North Hungary). - Általános Földtani Szemle, 16, pp. 35-88. (In Hungarian.)

B. Árgyelán, G., Z. Gulácsi 1997: Acidic extrusive and plutonic rocks fragments in the siliciclastic sediments of the Darnó and Szarvaskő Units. - Terra Nostra, Sediment'97 Kurzfassungen, p. 3.

Borojević, S., L.A. Palinkaš, V. Bermanec 2000: Fluid inclusions in Pillow Lavas of Hruškovec, Mt. Kalnik. - Zbornik radova 2. Hrvatski Geološki Kongres, pp. 123-125.

Capedri, S, G. Venturelli, G. Bocchi, J. Dostal, G. Garuti, A. Rossi 1980: The geochemistry and petrogenesis of an ophiolite sequence from Pindos, Greece. - Contr. Mineral. Petrol., 74, pp. 189-200.

Chiari, M., M. Marcucci, G. Cortese, A. Ondrejcikova, A. Kodra 1996: Triassic radiolarian assemblages in the Rubik area and Cukali zone, Albania. - Ofioliti, 21, pp. 77-84.

Csontos, L. 1999: Structural outline of the Bükk Mts., N Hungary. - Földtani Közlöny, 130 /1, pp. 95-131.

Danelian, T., A.H.F. Robertson 2001: Neotethyan evolution of eastern Greece (Pagondas Mélange, Evia island) inferred from radiolarian biostratigraphy and the geochemistry of associated extrusive rocks. - Geological Magazine, 138/3, pp. 345-363, Cambridge.

De Wever, P. 1984: Triassic radiolarians from the Darnó area (Hungary). - Acta Geologica Hungarica, 27/3-4, pp. 295-306.

Dimitrijević, M.D. 2001: Dinarides and the Vardar Zone: a short review of the geology. - Acta Volcanologica, 13/1-2, pp. 1-8.

Dimitrijević, M.N., M.D. Dimitrijević, S. Karamata, M. Sudar, N. Gerzina, S. Kovács, L. Dosztály, Z. Gulácsi, Gy. Less, P. Pelikán 2003: Olistostrome/mélanges - an overview of the problematics and preliminary comparison of such formations in Yugoslavia and NE Hungary. - Slovak Geological Magazine, 9/1, pp. 3-21.

Dimitrijević, M.N., M.D. Dimitrijević, Z. Radovanović, J. Obradović, N. Vasić, D. Milovanović 1996: The "Diabase-Chert" Formation. - In: Dimitrijevic, M.D. (Ed.): Geology of Zlatibor, pp. 41-47, Geoinstitute, Special Publication 18, Beograd. (In Serbian, with English summary.)

Dosztály, L. 1994: Mesozoic radiolarian investigations in Northern Hungary. - manuscript, unpublished thesis, Hungarian Geological Institute, Budapest. (In Hungarian.)

Dosztály, L., S. Józsa 1992: Geochronological evaluation of Mesozoic formations of Darnó Hill at Recsk on the basis of radiolarians and K-Ar age data. - Acta Geologica Hungarica, 35/4, pp. 371-393.

Dosztály, L., S. Józsa, S. Kovács, Gy. Less, P. Pelikán, Cs. Péró 2002: North-East Hungary. 1st Day Programme, Post-Congress Excursion C. - In: Vozár, J., R. Vojtko, L. Sliva (Eds): Guide to Geological Excursions, XVIIth Carpathian-Balkan Geological Association, pp. 104-117, Bratislava, Slovak Republic.

Ferrière, J. 1976: Sur la signification des séries du massif de l'Othrys (Gréce continentale orientale): la zone isopique maliaque. - Annales Societé géologique du Nord, 96, pp. 121-134. 
Ferrière, J. 1982: Paléogéographies et tectoniques superposées dans les Hellénides internes: Les Massifs de Othrys et du Pelion (Grèce continentale). - Societé géologique du Nord, Publication no. 8, pp. 1-970.

Fülöp J. 1994: Magyarország földtana. Paleozoikum II. (Geology of Hungary. Paleozoic II). Akadémiai Kiadó, 447 p. (In Hungarian.)

Gawlick, H.-J., W. Frisch, L. Hoxha, P. Dumitrica, L. Krystyn, R. Lein, S. Missoni, F. Schlagintweit 2008: Mirdita Zoneophiolites and associated sediments in Albania reveal Neotethys Ocean origin. - International Journal of Earth Sciences (Geologische Rundschau), 97, pp. 865-881.

Gorican, S., J. Halamić, T. Grgasović. T. Kolar-Jurkovšek 2005: Stratigraphic evolution of Triassic arcbackarc system in northwestern Croatia. - Bulletin Societé Géolologique de la France, 176/1, pp. 3-22.

Haas, J. 2008: A bükki-darnói jura képződmények ôsföldrajzi helyzete és kapcsolatai (Paleogeographical setting and relationships of the Jurassic formations in the Bükk-Darnó area) - (In Hungarian, with English abstract.) - MÁFI Évi Jel., 2006, pp. 85-95.

Haas, J., Á. Görög, S. Kovács, P. Ozsvárt, I. Matyók, P. Pelikán 2006: Displaced Jurassic foreslope and basin deposits of Dinaridic origin in Northeast Hungary. - Acta Geologica Hungarica, 49/2, pp. $125-163$.

Haas, J., S. Kovács 2001: The Dinaridic-Alpine connection - as seen from Hungary. - Acta Geologica Hungarica, 44/2-3, pp. 345-362.

Halamić, J., S. Gorican 1995: Triassic radiolarites from Mts. Kalnik and Medvednica (Northwestern Croatia). - Geologica Croatica, 48/2, pp. 129-146.

Halamić, J., S. Gorican, D. Slovenec, T. Kolar-Jurkovšek 1999: A Middle Jurassic radiolarite-clastic succession from the Medvednica Mt. (NW Croatia). - Geologica Croatica, 52/1, pp. 29-57.

Halamić, J.,V. Marchig, S. Gorican 2001: Geochemistry of Triassic radiolarian cherts in northwestern Croatia. - Geologica Carpathica, 52/6, pp. 327-342.

Halamić, J., D. Slovenec, T. Kolar-Jurkovšek 1998: Triassic pelagic limestones in pillow lavas in the Orešje Quarry near Gornja Bistra, Medvednica Mt. (Northwest Croatia). - Geologica Croatica, 51/1, pp. 33-47.

Jacobshagen, V. 1986: Geologie von Griechenland. - Gebrüde Borntraeger, Berlin - Stuttgart, 363 p.

Jones, G., A.H.F. Robertson 1991: Tectonostratigraphy and evolution of the Pindos Mountains, northwest Greece. - Journal of the Geological Society, London, 148, pp. 267-288.

Józsa, S. 1999: Petrology and geochemistry of ocean floor magmatic rocks of Darnó Hill, NE Hungary. - PhD thesis, Eötvös University, Budapest.

Józsa, S., L. Dosztály, Z. Gulácsi, S. Kovács 1996: Ophiolites of Szarvaskő, Darnó Hill and Bódva Valley (Summarized characteristics of North Hungarian ophiolitic magmatic rocks.) - IGCP 369 workshop on "Rift magmatism", Field guide B: Ophiolitic units in NE Hungary, 16 p., Budapest.

Karamata, S., V. Knezević, V. Cvetković 2000: Petrology of the Triassic basaltoid rocks of Vareš (Central Bosnia). - Acta Geologica Hungarica, 43/1, pp. 1-14.

Kaufmann, G. 1976: Perm und Trias in Östlichen Mittelgriechenland und auf einigen Ägaischen Inseln. - Zeitschrift der deutsche geologische Gesellschaft, 127, pp. 387-398.

Kemp, A.E.S., A. McCaig 1984: Origins and significance of rocks in an imbricate thrust zone beneath the Pindos ophiolite, nortwestern Greece. - In: Robertson A.H.F., J.E. Dixon (Eds): The Geological Evolution of the Eastern Mediterranean. Journal of Geological Society, London, Spec. Publ., 17, pp. 569-580.

Kiss, G. 2007: Szubmarin vulkanizmushoz kapcsolódó hidrotermás események jellemzése a Darnózóna párnaláváiban. (Characterization of hydrothermal events connected to submarine volcanism in the pillow lavas of Darnó Zone.) - Manuscript, 44p., 10 pls., Department of. Mineralogy, Eötvös University, Budapest. (In Hungarian.)

Kiss, G., F. Molnár., L. Palinkas 2008: Volcanic facies and hydrothermal processes in Triassic pillow basalts from the Darnó Unit, NE Hungary. - Geologica Croatica, 61/2-3, pp. 385-394.

Kiss, G., F. Molnár, L.A. Palinkaš, S. Kovács, H. Hrvatović (in press): Correlation of Triassic advanced rifting related Neotethyan submarine basaltic volcanism of the Darnó Unit (NE Hungary) with 
some Dinaridic and Hellenidic occurrences on the basis of volcanological, fluid-rock interaction and geochemical characteristics - International Journal of Earth Sciences.

Kiss, J. 1958: Ércföldtani vizsgálatok a siroki Darnó-hegyen. (Untersuchungen der vererzung des Darnóberges im Mátragebirge.) (In Hungarian, with German abstract.) - Földtani Közlöny, 88/1, pp. 27-41.

Kovács, S. 1984: North Hungarian Triassic Facies Types: A review. - Acta Geologica Hungarica, 27/3, pp. 251-264.

Kovács, S., S. Józsa, Z. Gulácsi, L. Dosztály, G. B.-Árgyelán, M. Forián-Szabó, P. Ozsvárt 2005: PermoMesozoic Formations of the Darnó Hill Area, NE Hungary - A Displaced Fragment of the Inner Hellenidic-Inner Dinaridic Accretionary Complexes. - In: Tomljenovic, B., D. Balen, I. Vlahovic (Eds): 7th Workshop on Alpine Geological Studies. Abstracts Book. Croatian Geological Society, Zagreb, pp. 51-52.

Kovács, S., J. Haas, G. Szebényi, Z. Gulácsi, S. Józsa, P. Pelikán, G. Bagoly-Árgyelán, Á. Görög, P. Ozsvárt, Zs. Gecse, I. Szabó 2008: Permo-Mesozoic formations of the Recsk-Darnó Hill area: stratigraphy and structure of the Pre-Tertiary basement of the Paleogene Recsk Ore Field. - In: Födessy, J., É. Hartai (Eds): 2008: Recsk and Lahóca: Geology of the Paleogene Ore Complex. Geosciences, Publications of the University of Miskolc, Ser. A., Mining, Vol. 73.

Kovács, S. 2010: Type section of the Triassic Bódvalenke Limestone Formation (Rudabánya Mts., NE Hungary) - the northwesternmost occurrence of a Neotethyan deep water facies. - (this volume.)

Less, Gy. 2000: Polyphase evolution of the structure of the Aggtelek-Rudabánya Mountains (NE Hungary), the southernmost element of the Inner Western Carpathians - a review. Slovak Geological Magazine, 6, pp. 260-268.

Marcucci, M., A. Kodra, A. Pirdeni, T. Gjata 1994: Radiolarian assemblages in Triassic and Jurassic cherts of Albania. - Ofioliti, 19/1, pp. 105-114.

Migiros, G., V. Tselepidis 1990: Der erste Nachweis von Hallstatter Kalken in der North-PindosDecke (NW-Griechenland). - Neues Jahrbuch für Geologie und Paläontologie, Monatshefte, 1990/4, pp. 248-256.

Migiros, G., E. Gartzos, S. Józsa, S. Kovács, V. Tselepidis, L. Dosztály, Z. Gulácsi 1998: Ophiolite complexes/oceanic assemblages in Northern Greece (Othrys and North Pindos Mountains) and NE Hungary: Remnants of the (Neo)Tethys oceanic system - Geological setting, geochemistry, radiolarian biostratigraphy and geotectonic comparison. - XVI Congress Carpathian-Balkan Geological Association, Abstracts, p. 382, Vienna.

Obradović, J., S. Gorican 1988: Siliceous deposits in Yugoslavia: Occurences, Types and Ages. - In: Hein, J.H., J. Obradovic (Eds): Siliceous Deposits of the Tethys and Pacific Regions, SpringerVerlag, New York, pp. 51-64.

Ozsvárt, P., L. Dosztály, G. Migiros, V. Tselepidis, S. Kovács (in press): New radiolarian biostratigraphic age constraints on Middle Triassic basalts and radiolarites from the Inner Hellenides (Northern Pindos and Othris Mountains, Northern Greece) and their implications for the geodynamic evolution of the early Mesozoic Neotethys. - Int. J. Eart. Sci., DOI: 10.1007/s00531-010-0628-9

Palinkaš, L., V. Bermanec, M. Vrkljan, S. Medimorec 1998: Pillow lavas from Hruškovec, North Croatia: Rifting magmatism or dismembered ophiolitic sequence? - Workshop of IGCP Project No. 369: "Magmatism and Rift basin evolution", Abstracts, p. 84, Prague.

Palinkaš, L., T. Kolar-Jurkovšek, S. Borojević, V. Bermanec 2000: Triassic rifting magmatism within Zagorje-Mid-Transdanubian zone, examplified by pillow lavas of Hruškovec, Mt. Kalnik, N Croatia. - PANCARDI 2000, Vijesti Hrvatskog geološkog drustva, 37/3, pp. 98-99.

Palinkaš, A.L., V. Bermanec, S. Borojević-Šoštarić, T. Kolar-Jurkovšek, T. Strmić S. Palinkaš, F. Molnár, G. Kniewald 2008: Volcanic facies analysis of a subaqueous basalt lava-flow complex at Hruškovec, NW Croatia - evidence of advanced rifting in the Tethyan domain - J. of Volc. and Geotherm. Res., 178, pp. 644-656. 
Pamić, J. 1963: Trijaski vulkaniti okolice Cevljanovica i kratak osvrt na trijaski vulkanizam zone Borovica-Vareš-Cevljanovici (Triassic volcanic rocks of Cevljanovici and short regards to Triassic volcanism of the Borovica-Vareš-Cevljanovici zone). - Geološki glasnik, 7, pp. 9-20, Sarajevo.

Pamić, J. 1997: The northwestern outcrops of the Dinaridic ophiolites: a case study of Mt. Kalnik (North Croatia). - Acta Geologica Hungarica, 40/1, pp. 37-56.

Pamić, J. 2003: The allochthonous fragments of the Internal Dinaridic units in the western part of the Pannonian Basin. - Acta Geologica Hungarica, 46/1, pp. 41-62.

Pamić, J., S. Kovács, J. Vozár 2002: The Internal Dinaridic fragments into the collage of the South Pannonian Basin. - Proceedings of the XVIIth Congress of Carpatho-Balkan Geological Association, Geologica Carpathica, 53, Spec. Issue, pp. 9-11.

Pamić, J., B. Tomljenović 1998: Basic geological data on the Croatian part of the Zagorje-MidTransdanubian Zone. - Acta Geologica Hungarica, 41/4, pp. 389-400.

Papanikolaou, D. 1986: Geology of Greece (in Greek). 240 p., Athens.

Pe-Piper, G. 1998: The nature of Triassic extension-related magmatism in Greece: evidence from $\mathrm{Nd}$ and $\mathrm{Pb}$ isotope geochemistry. - Geological Magazine, 135, pp. 331-348.

Popević, A. 1970: A contribution to the knowledge of the Diabase-Chert Formation in the neighbourhood of Priboj bath. - Annales géologiques de la Péninsule Balkanique, 35, pp. 137-150. (In Serbian, with English summary.)

Richter, D. 1976: Das Flysch-Stadium der Helleniden-Ein überblick. - Zeitschr. Geol. Gesellsch., 127, pp. 467-483.

Saccani, E., E. Padoa, A. Photiades 2003: Triassic mid-ocean ridge basalts from the Argolis Peninsula (Greece): new constraints for the early oceanization phases of the Neo-Tethyan Pindos basin. Journal of Geological Society, London, Spec. Publ., 218, pp. 109-127.

Sadek, Gh., P. Árkai, G. Nagy 1996: Alpine polyphase metamorphism of the Szarvaskő complex, Bükk Mountains, Hungary. - Acta Minerologica-Petrographica, Szeged, 37, pp. 99-128.

Schréter, Z. 1952: A Mátrától ÉK-re eső dombvidék földtani viszonyai (Geology of the hilly region NE of the Mátra Mts). - (In Hungarian with French and Russian abstract) MÁFI Évi Jel. 1948, pp. 111-119.

Skourtsis-Coroneou, V., V. Tselepidis, S. Kovács, L. Dosztály 1995: Triassic pelagic sedimentary evolution in some geotectonic units in Greece and Hungary: a comparison. - 15th Congress Carpatho-Balkan Geological Association, Geological Society of Greece, Special Publication No. 4/1, pp. 275-281.

Sztanó, O., S. Józsa 1996: Interaction of basin-margin faults and tidal currents on nearshore sedimentary architecture and composition: a case study from Early Miocene of northern Hungary. - Tectonophysics, 266, pp. 319-341.

Kovács, S., M. Sudar, S. Karamata, J. Haas, Cs. Péró, E. Gradinaru, H.-J. Gawlick, M. Gaetani, J. Mello, M. Polák, D. Aljinović, B. Ogorelec, T. Kolar-Jurkovšek, B. Jurkovšek, S. Buser. (in press): Triassic environments in the Circum-Pannonian region related to the initial Neotethyan rifting stage. - Jahrbuch der Geologischen Bundesanstalt, 151/2.

Varga, Gy., E. Csillag-Teplánszky, Zs. Félegyházi 1975: Geology of the Mátra Mountains. - MÁFI Évkönyve, 57/1, 575 p., Budapest. (In Hungarian, with English summary.)

Zelenka, T., Cs. Baksa, Z. Balla, J. Földessy, K. Földessy-Járányi 1983: The role of the Darnó Line in the basement structure of Northeastern Hungary. - Geologicky Zbornik - Geologica Carpathica, 34/1 pp. 53-69. 